SYLWIA MOCHOCKA*

\title{
Mieszkać w wielkiej płycie
}

\section{Living in a prefab}

Streszczenie

Osiedla z wielkiej płyty stanowią istotny element urbanistyczny wielu polskich miast. Tego typu zespoły, budynki oraz prze pojawi sie pytanie: czy powinniśmy je wyburzać i tworzyć na ich miejscu nowe, czy też poddawać je działaniom rehąślie cyinym? Zdaniem autorki artykułu najutaściwszym kierunkiem dziatán jest ich rehabilizacja. Osiedla mieszkaniowe z wielkie płyty maja duże możliwości, aby poprzez szereg przekszatałceń stać sie miejscem dostosowanym funkcjonalno-przestrzenni do potrzeb ich mieszkańców N Natomiast przestrzenie społeczne i publiczne powstałe poprzez rehabilitacie moga wpłyná na aktywizacje całego miasta. Autorka artykułu na podstawie wybranych kieleckich osiedli z wielkiej płyty dokona oceny osied wielkiej płyty, jako wspótczesnego miejsca zamieszkania. Wyznaczy ich gtówne atuty oraz wskaże wady, które jej zdaniem należy uwzględnić podczas ewentualnych prac rehabilitacyjnych.

Abstract

Housing estates are an important urban element in many Polish cities. These types of complexes, buildings and spaces do not meet the modern human needs arising from the function of an apartment. The question arises ever so often: should we demolish them and create new ones in their place, or should we renovate them? According to the author of the article, the most appropriate course of action is their renovation. Large-panel housing estates have great opportunities to become a place adapted to the needs of their residents through a series of transformations. In contrast, social and public spaces created through renovation can affect the vitality of the entire city. The author of the article, on the basis of selected large-pane the main strengths and indicate the defects that she thinks should be taken into account during any renovation measures.

owa kluczowe: osiedla z wielkiei plyy, achitektura mieszkaniowa Kielc, reh

Wprowadzenie

Okresie powojennym mieszkania z wielkiej płyty wy dawały się być najlepszym rozwiązaniem kryzysu ekonomicznego i społecznego, a w tym tzw. "wielkiego gło du mieszkaniowego". W momencie swojej świetnośc osiedla prefabrykowane stanowity miejsce zamieszkania kojarzone z wyższym statutem społecznym oraz były jemy my zatem stwierdzić, że spełniły one częściowo swoje pierwotne założenia

ozwój cywilizacyjny i ekonomiczny ostatnich lat spomiejsa zamia oczekiwan spoleczenstwa względem kojarzyć z licznymi problemami natury architektoę nej, ekonomicznej oraz spotecznej, które miedzy innmi sa wynikiem przyjetych rozwiazań projektowych, jak i w dużym stopniu zmiennych w czasie potrzeb coraz bardziej świadomego człowiek

Należy zwrócić uwage, że sytuacja obiektów z wielkiej płyty jest różna w zależności od lokalizacji geograficznej jak i sytuacji ekonomicznej państwa, czy regionu, w którym się znajduja. Przykładem moga być osiedla w byłym NRD, które w momencie zjednoczenia kraju po 1989 roku, zaczeły "masowo pustoszeć". Gwałtowny odpływ ludności był przyczyną ich destrukcji, m.in. rozwoju przestępczości. Sytuacja ta wymusiła konieczność na-

\section{Introduction}

the post-war period, large-panel housing seeme be the best solution to the economic and socia crisis, including the so-called "Great hunger for hous ing." At the time of its splendour, prefabricated housgitates were a place of residence associated with ang only chance to wn a flat. We can therefore conclude that they partly met their original assumptions.

telopment of recent years the place of residence. The large-pan egardestates began to be associated with numerous probems of an architectural economic and social nature, which, among other things, are the result of accepted design solutions and to a brge extent, the needs of an increasingly conscious human that change over time. It should be noted that the situation of large-pane buildings varies depending on the geographical location as well as the economic situation of the country or region in which they are located. An example would be estates in the former GDR (East Germany - Germa Democratic Republic), which at the time of the unification of the country after 1989, began to be massively abandoned. The rapid outflow of population was the cause of their downfall, including development of tychmiastowej reakcji ze stron wladz, w kierunku rewitalizacji tych obszarow i przerwaniu ich dalszej degradaci, ktora moglaby mieć negatywny wpływ na cały kraj. Osiedla z wielkiej płyty w Polsce wydaja się byc w lepszej sytuacji niż wspomniane niemieckie. Do dziś stanowią one znaczny procent zamieszkałej tkanki polskic miast. Analizując układy funkcjonalne samych mieszka można zauważyć, że nie odbiegają one metrażem od współcześnie budowanych obiektow mieszkaniowych. Jest to jeden z czynników wpływających na ich ciaggta atrakcyjnośc, jako miejsca zamieszkania, w szczegól nosci dla mlodych osob, kóre ze względu na obecne wysokie ceny nowych mieszkan, nie moga pozwolic sobie na ich zallup. Fakt ciaglego zain mosowania tego we wspomninych osiedlach dziatan preprowadzane czy rehabiltacyine poprawiaja ich atrakeyiność oraz korygujace ich naiważiejse wady, gómnie techniczne Dziatania to, pomimo, ż nie stanowia kompleksowych przeksztatceń, maja znaczacy wptyw na wybór danego osiedla, czy bloku na miejsce zamieszkania.

Zdaniem autorki artykułu polskie osiedla z wielkiej płyty nadal stanowia duże zainteresowanie wśród kupujacych. Nie ulega jednak watpliwości, że są one poważne zużyte oraz nie spełniaja współczesnych tendencji wynikających ze zrównoważonego rozwoju, będącego wyznacznikiem współczesnej przestrzeni mieszkalnej. Fak ten niewatpliwie bedzie mieć $w$ przyszłości wpływ $n$ zmniejszenie ich atrakcyjności i potencjału, jako miejsca zamieszkania.

W zwiazku z powyższym, działania rehabilitacyjne w badanych osiedlach są niezbędne i należy szukać możlwosci ich realizacji, tak aby poprawić stan środowiska mieszkaniowego oraz wpłynąc na zainteresowanie nim wśród młodych pokolen

Podstawą wszelkich przekształcen powinno być dążenie do przystosowania istniejącej tkanki mieszkaniowej do zmieniających się w czasie potrzeb uźytkownikow oraz zasad zrownoważonego rozwoju. W tym celu należy $n$ bieżąco analizowac problemy osiedlowe oraz dokony wać dokładnej oceny wielkości zjawiska ich degradacji. Poniżej przedstawiono wyniki analiz osiedli mieszkaniowych z wielkej plyty preprowadzonych na podstawi wybranych kieleckich osiedli mieszkaniowych.

Kielce - osiedla z wielkiej płyty

Wspótcześnie osiedla z wielkiej płyty te są w złym stanie technicznym oraz podlegają ciągłemu procesow degradacji. Sposób ich budowania, opierający się na o stałych parametrach wielkoscowych, wpłynął na powtarzalność kolejnych kondygnacji, jak i całych budynków. Dodatkowo standardowe wielkości prefabrykatów wpłynęły na brak elastyczności mieszkań, oraz znacząco utrudnity ich zróżnicowanie pod względem funkcjonalnym. Bryły budynków pozbawione sa detalu, a ich forma jest maksymalnie uproszczona. Na drugim planie pozostawiano również zagospodarowanie terenu.

Analizując kieleckie osiedla mieszkaniowe z wielkiej płyty zauważyć można, że posiadają one również pewne atuty. Między innymi jest to obecnosc duzych niezagospoda- crime. This situation forced the need for immediate reareas and stopping their further degradation, which could have a negative impact on the entire country. Large-panel housing estates in Poland seem to be in a better position than the German ones mentioned above. To this day, hiey consticute a significant percentage of the inhabited fabric of Polish cities. Analyzing the functional layouts of the flats, they do not differ in size from the currently constructed housing facilities. This is one of the factors affecting their continuous attractiveness as a place of residence, in particular for young people who, due to the current high prices of new apartments, cannot afford to buy them. The fact of continuous interest in this type of housing is confirmed by upgrade or revitalisation activities carried out in the said housing estates, improving their attractiveness and correcting their most important flaws, mainly technical. These activities, despite the fact that they are not comprehensive transformations, have a significant impact on the choice of given housing estate or a block of flats.

According to the author of the article, Polish large panel housing estates are very popular among buy ers. There is no doubt, however, that they are serously worn and do not meet modern trends resulting from sustainable development, which is a determnant of modern living space. This fact will undoubedly have an impact on reducing their attractiveness and potential as a place of residence in the future. in ties in the exarilties housing estates are necessary and the possibilites of their inplementation should ing enviro ant and to attrat The basis for all transformations should be striving to basis for all transforitions should be striving residets and the principles of sustainate development tha change over time. To this end, housing rence ough assessment of their degradation extent should be made.

Below are the results of analyzes of large-panel housing estates carried out on the basis of selected housing estates in the city of Kielce.

Kielce - large-panel housing estates

Today, large-panel housing estates are in poor technical condition and undergo a continuous degradation process. The way they were built, based on same-size prefabricated units, influenced the repeatability of subsequent floors as well as entire buildings. In addition, the standard sizes of prefabricated units resulted in a lack of flexibility of flats, and significantly hindered their functional diversity. The building blocks are devoid of detail and their form is simplified at the maximum. Land development was also shifted into the background.

Analyzing the large-panel housing estates of the city of Kielce, they also have some advantages. Among 


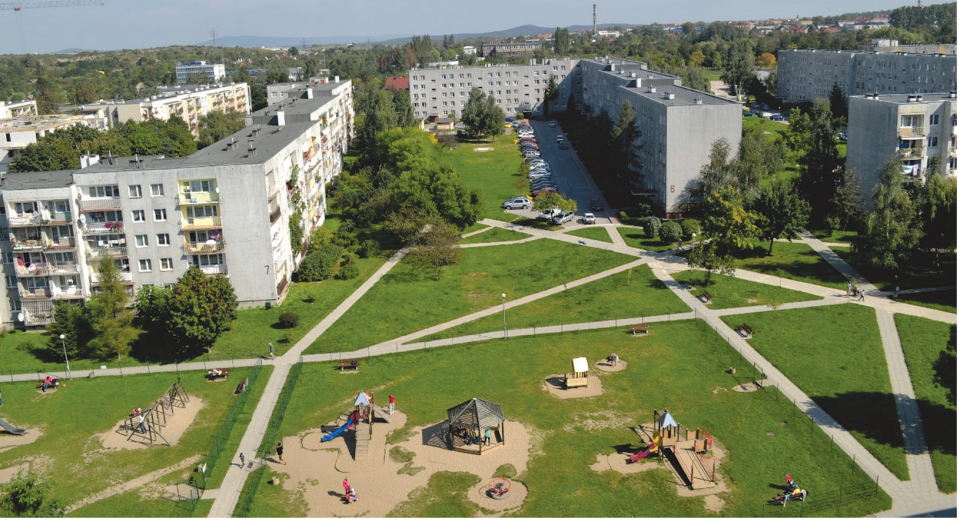

II. 1. Zielona przestrzeń biegnaca przez osiedle Barwinek (fot. auto
Green area of the Barwinek housing estate (photo by the author)

rowanych terenów zielonych, które przy odpowiednim podejściu mogłyby stać się elementem wyróżniającym je spośród współczesnych zespołów.

W przypadku osiedla Barwinek zielona przestrzeń stanowi oś kompozycyina taczaca pótnocna cześć osiedla z powi os kompozycyjną łącząca połnocną czésć osiedla z poprzestrzé stanowi swego rodzaju punt orientelon przestrzen stanowi swego rodzaju punkt orientacyjny
oraz prowadzi do Rezerwatu Skalnego Ślichowice. ${ }^{2}$ (il. 2) oraz prowadzi do Rezerwatu Skalnego Slichowice. ${ }^{2}$ (il. 2) w Polsce zanotowano w latach 70 i 80-tych. Podobna sytuacja występuje w Kielcach, gdzie pierwsze pojedyncze bloki z wielkiej płyty powstały już w latach 50-tych $X X$ wieku.

Natomiast największy rozwój „wielkiej płyty” w Kielcach datuje się na lata 70-te XX wieku. Wtedy to powstały bloki na osiedlu Chęcińskim, jak i rozbudowywała się dalsz część osiedla Jagiellońskiego.

Lata 70-te to początek budowy osiedla Herby. W 1975 RSM "Armatury" przystąpita do budowy osiedla Pod Karczówką. W latach 1971 - 1974 Kielecka Spółdzielnia Mieszkaniowa rozpoczęła realizację budynków na osiedlach Bocianek i Sady, a w roku 1975 rozpoczęto budowe osiedla Uroczysko.

Lata 80-te to dalszy rozwój północnej części Kielc. W roku $1980 \mathrm{w}$ połnocnych dzielnicach miasta rozpoczęto realizację osiedii Na Stoku, Słoneczne Wzgórze oraz Swiętokrzyskie. W latach 80-tych nastąpił równiez rozwój południowej częśsi Kielc, mi.in. osiedla Barwine oraz dalsza rozbudowa osiedla Herby. W 1986 r. powstata Spóldzielnia Mieszkaniowa "Domator, ktora swoja dzialalnosć rozpoczęla od budowy bloków w zachodnie li Szsci miasta od ósiedla Pod Dahią, a następnie osiedir Slichowice I S Slichowice ll, będacymi najmiodszym osledlami z wielkiej plyty w Kielcach

whejech preprowadzonych w kieleckich osiedlach z wielkiej plyty $z$ podziałem $n$

\section{Rozwiązania komunikacyjne}

Na osiedlach $z$ wielkiej płyty występuje ogólny problem z rozwiązaniem komunikacji wewnątrzosiedlowej. Brakuje podziału na komunikacje kołowa, piesza oraz rowerowa. Kielce sa miastem średniej wielkości w zwiazku z czym osiedla w większości mają dobre połączenia zarówno transportem indywidualnym, jak i komunikacja zbioro- other things, it is the presence of large undeveloped green areas, which, with the right approach, could become an element that distinguishes them from modern complexes.

In case of the Barwinek housing estate, the green space is the compositional axis connecting the northenc and southern parts of the estate (ill. 1$)$, while a the Slichowice housing estate the green space is a kind of landmark and leads to the Slichowice Rock Reserve. ${ }^{2}$ (ill. 2 )

The greatest intensification of large-panel residential housing in Poland followed in the 70's and 80's. A similar situation applies to Kielce, where the firs individual prefabs were created in the 1950 .

However, the largest large-panel development in Kielce dates back to the 1970s. At that time, blocks of flats were built at the Chęcinskie housing estate as well as the further part of the Jagiellońskie housing estate was developed.

The 70 's were the beginning of the construction of the Herby housing estate. In 1975, RSM "Armatury" started building the Pod Karczówka housing estate In the years 1971-1974, Kielecka Spótdzielnia Miesz kaniowa (housing co-operative of Kielce) started the construction of buildings in the Bocianek and Sady housing estates, and in 1975, the construction of th Uroczysko housing estate began.

The 1980s involved a further development of the northern part of Kielce. In 1980, the housing estates an to be buit in the nororze and Swiętokrzyskie began to be built in the northern districts of the city. In the 80s, her was also the development or he southen part of Kicle, among others, Barwirk housing esta in 1986, the "Domator" Housing Coousing was established, which begn its activity by bilding bas in the whe wo bu

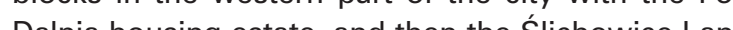
Ślichowice ll housing estates, which are the youngest Show The following are the results of andyzes performed in the large-panel housing states of Kielce, livided in communication, functionality, space and program.

\section{Communication}

In large-panel housing estates there is a general problem with local communication. There is no division into roads, pedestrian routes and bicycle paths. The city of Kielce is a medium-sized city, therefor the housing estates are mostly provided with good individual and public transport links from the centre. In case of larger housing estates, such as the $\mathrm{Na}$ Stoku or Ślichowice housing estate, the road from the complex centre to the nearest stop is slightly longer and it is a significant obstacle for people using public transport.

The analysis showed lack of bicycle path links of large-panel housing estates with the city. This problem is related to the development of the communication infrastructure of the entire city of Kielce, namely

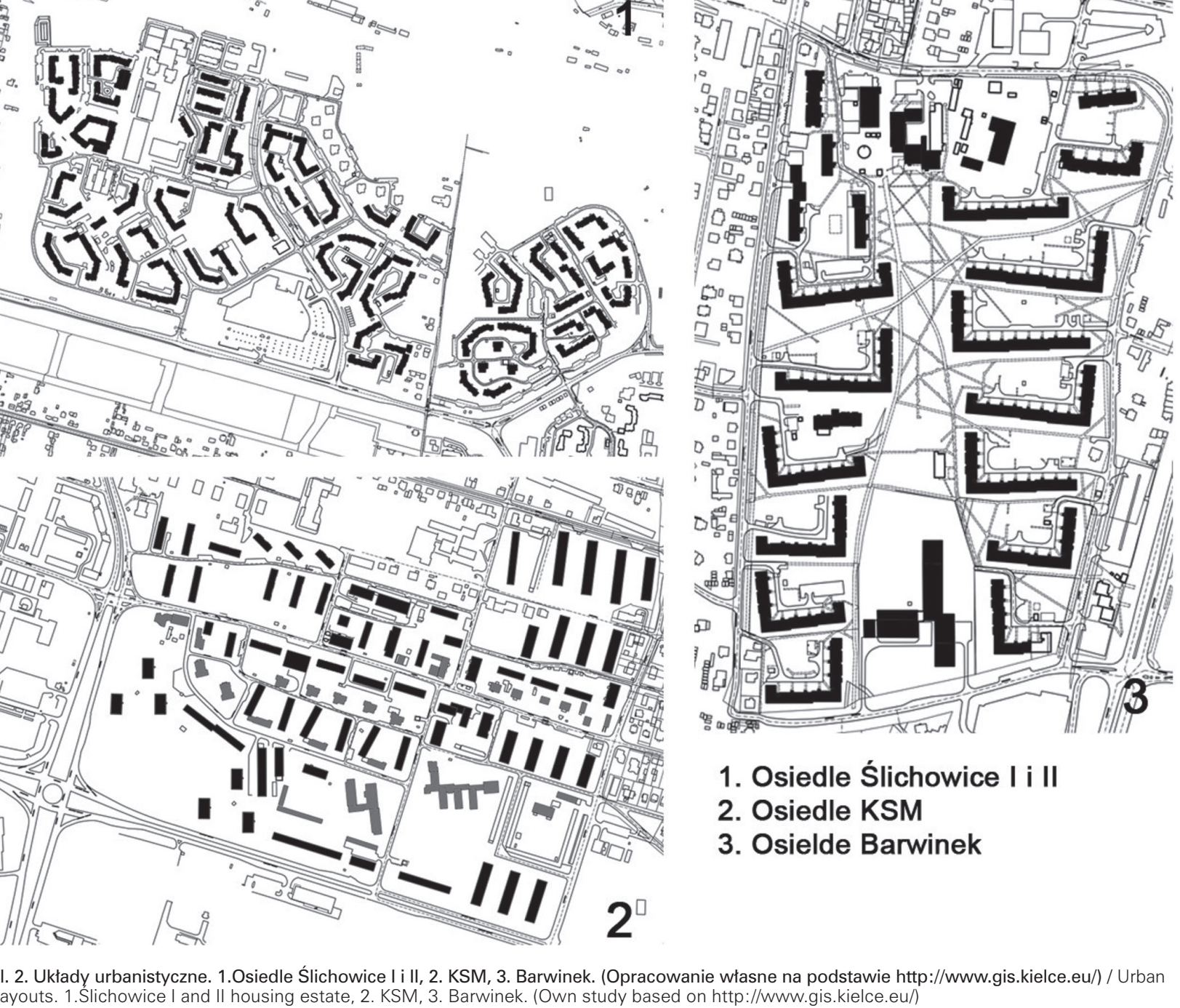

wą z centrum. W przypadku większych powierzchniowo osiedli, jak osiedle Na Stoku, czy też Ślichowice drog z centrum zespolu do najblizszego przystanku jest nieco dłuższa oraz stanowi znaczne utrudnienie dla osób kozystających z miejskiej komunikacjl.

Analiza wykazała brak połączeń osiedli z wielkiej płyty z miastem poprzez system scieżek rowerowych. Probz ming nikacyjnej calego miasta Kielce, a mianowicie brakiem cych so systemu scieżk row a milowch, umozliwajanego punktu w mieście.

W czosa budowy zespotów wielkopłytowych ciagi piwze nie byty dostosowywane dil wszystkich uiytkowników np. osób poruszajacych sie na wózkach. Anawnizu tan techniczny oben infrastruktury komunikacyine wewnatr osiedli prefabrykowanych zauwazany iest brak dostępności dla wszystkich, jak i obecność licznych barier architektonicznych i urbanistycznych m in: schody terenowe, wysokie krawężniki. Dodatkowo wiek osiedli wpłynął na zły stan nawierzchni, która jest nie równa i zniszczona. (il. 3)

Dużym problemem jest niedostateczna ilość miejsc parkingowych w stosunku do ilości samochodów. Na osiedlach brakuje miejsc postojowych oraz zamkniętych garaży. Na niektórych z nich, jak w przypadku Barwinka obecne są parkingi płatne, z ktorych korzystają głównie osoby przyjeżzzające do pracy. the lack of a coherent system of bicycle paths, en abling efficient cycling to any point in the city.

At the time of the large-panel complex construction pedestrian routes were not adapted to all users, e.g. people in wheelchairs. Analyzing the technical condition of the current communication infrastructure sibility for everyone is noticeable, as well as the presg. e. ment, which is uneven and damaged. (ill. 3)

Insufficient parking spaces in relation to the number of cars are also a big problem. The housing estates lack car parks and closed garages. On some of them as in case of Barwinek, there are paid car parks, used mainly by people commuters.

There is a noticeable phenomenon of vehicles parking between buildings, on residential streets as well as in green spaces. This phenomenon is a cause of playgrounds. (ill. 4) Poorly resolved transport infrastructure significantly affects the quality of everyday life of residents, reduces the utility values of the estate and is a threat.

The lack of parking places forces the construction of car park indoors between buildings. A very unfavourinside prefabricated housing estates, a lack of accesdiscomfort, noise, air pollution and is a danger in spaces that should be used for recreation, eg. at 


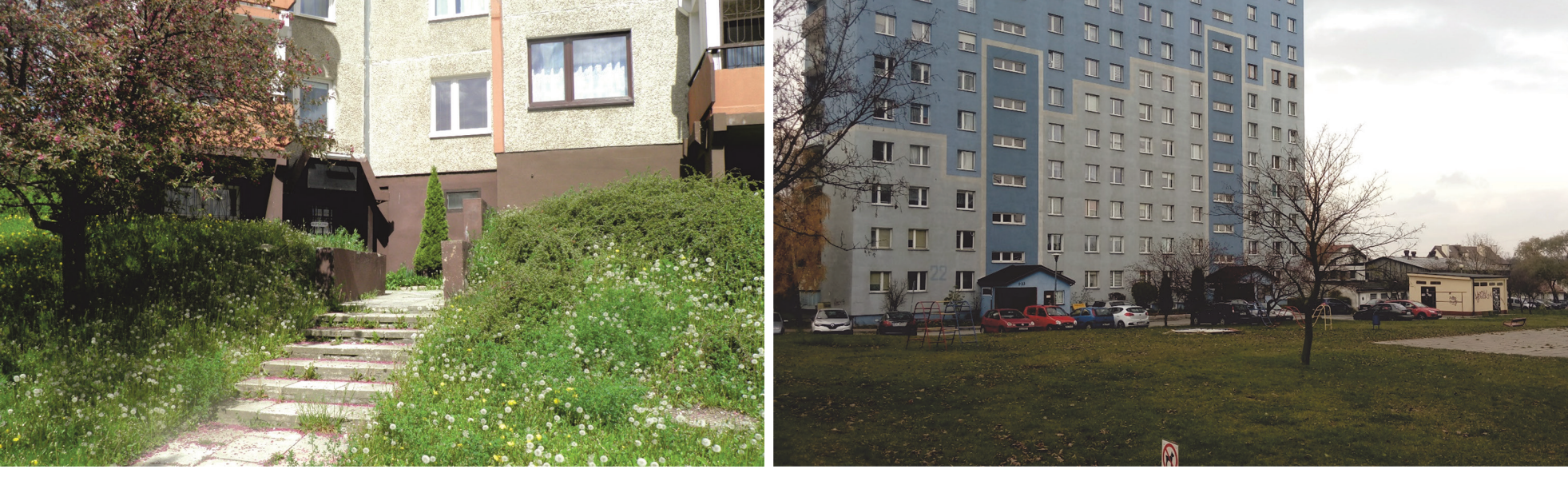

II. 3. Schody terenowe. Osiedle Pod Dalnią (fot. autorka) / Terrain stairs. Pod Dalnia housing estate (photo by the author)

II. 4 . Parkingi w sasiedztwie placów zabaw. Osiedle Barwinek (fot. autorka) / Parking lots adjacent to playgrounds. Barwinek housing estate. (pho-
to by the author)

Zauważalnym jest zjawisko parkowania pojazdów we wnętrzach między budynkami, na osiedlowych sieciach ulicztrzach między budynkami, na osiedlowych sieciach ulicz-
nych, jak i w przestrzeniach zielonych. Zjawisko to jest ponych, jak i w przestrzeniach zielonych. Zjawisko to jest po-
wodem dyskomfortu, powoduje hałas, zanieczyszczenie wodem dyskomfortu, powoduje hałas, zanieczyszczenie
powietrza i stanowi niebezpieczeństwo w przestrzeniach, powietrza i stanowi niebezpieczeństwo w przestrzeniach, 4) Żle rozwiązana infrastruktura komunikacyjna znacząco wpływa na jakość codziennego życia mieszkańców, obniża walory użytkowe osiedla i stanowi zagrożenie.

Brak miejsc postojowych zmusza do budowania parkingów we wnętrzach między budynkami. Bardzo niekorzystne zjawisko zaobserwować można na osiedlu Barwinek, gdzie między budynkami nr 1 i 2 uprzednio zielona przestrzen o wysokich walorach estetycznych została w całości wyłożona kostką brukową i służy jako plac parkingowy. (il. 5)

Problemy z rozwiązaniami komunikacyjnymi są obecn nawet $w$ niektorych bardzo dobrze zaprojektowanych urbanistycznie zespolach. Jest to związane $z$ faktem, ż w czasach rozwoju wielkiej płyty transport samochodowy nie był powszechny, w związku z czym rozwiązani komunikaci nie bylo kluczowym problemem. W związku z czym początkowo dosc dobre zalożenia wraz z rozwojem cywilizacyjnym oraz zwiększającą się liczbą sawspółczesnych wymogów.

Rozwiązania fukcjonalno-przestrzenne i programowe Zespoły wielkopłytowe cechuje dość monotonna urbanistyka. Obecne są w nich liczne niezagospodarowane przedomin, objekty wiela aly obiekty ustugowe, czy tez obiekty ón. W W kielekich osiedlach dominuj oriekty 5 kon $y$ swacy. W dygnacyine. W strukturze miasta można wyróżnć kilk bardzo czy. Whych ukbóm urbanistycanch, jak osiedla Barwinek, Bocianek, czy też Ślichowice, jak i mniej czyteldogeszczania (osiedla Na Stoku czy też KSM (il. 2)). W przypadku zespołów, w których dominuja obiekty niania budynków. Nieodpowiednie odległości między budynkami zaobserwowano w osiedlach, gdzie dominują obiekty 11-kondygancyjne. able phenomenon can be observed in the Barwinek ousing estate, where the previously green space with high aesthetic values was entirely paved with paving stones and serves as a parking lot between buildings No. 1 and 2 (ill. 5)

Problems with communication solutions are presen even in some very well urbanized complexes. This is due to the fact that at the time of the large-panel development, car transport was not common, and therefore the solution of communication was not a key problem. Therefore, initially some good solutions along with the civilizational development and the increasing number of cars became unclear and

\section{Functional, spatial and program solutions}

Large-panel complexes are characterized by rather spaces that need to be vitalised. The structure of housing estates is dominated by multi-family buildings. In addition, service and educational facilities are present. The 5 -storey and 11-storey buildings dominate in the housing estates of the city of Kielce. The city structure distinguishes several very clear urban layouts, such as the Barwinek, Bocianek or Ślichowice housing estates, as well as less clear layouts in which the negative phenomenon of densification is noticeable (Na Stoku or KSM housing estates (ill. 2). buildings. Is uscally distances between building were observed in estates where 11-storey buildings -storey building

Among the large-panel complexes of Kielce one can also observe very large undeveloped green spaces that are not conducive to creating social bonds (Barwinek, Bocianek). It should be noted, however, that these spaces create ideal conditions for division into rivate, social and public spaces, and at the same time intimate areas, the so-called yards for better ientification and development of bonds among resdents. not adapted to modern requirements. dull urban planning. They have a lot of undeveloped

In case of complexes dominated by 5 -storey buildings, there is usually no
Wśród kieleckich zespołów wielkopłytowych zaobserwowac można rowniez występowanie bardzo duzych niezagospodarowanych przestrzeni zielonych, które nie sprzyjają tworzeniu więzi spolecznych (Barwinek, Bocianek). Należy jednak zwrócić uwagę, że przestrzenie te tworzą idealne warunki do podziału na przestrzen prywatną, spoleczną i publiczna, a zarazem powstaniu kameralnych wnętrz tzw. podworek, służących lepsz identyfikacji i budowaniu więzi wśród mieszkańców. Na osiedlach brakuje czytelnego podziału przestrzeni na strefe wejściowa, miejsca wspolnotowe, parkingi, place zabaw, czy też prywatne ogrody. (il. 6) Analiza wykazał potrzebe tworzenia tego typu przestrzeni, co potwierdza między íny i fakk, żécieszk roncy sami organizują sobie p. ogrodk przy wejściach do obiektow. (I. 7)

dįz pla mieszkancow pregra hruju placów zabaw, różnorodnych form służacych biernemu jak i czynnemu spedzaniu czasu. W przypadku wiekszości osiedli we wnetrzach miedzy budynkami obecne sa place zabaw, jednak ich stan techniczny nie pozwala na korzystanie z nich. (il. 8) Zauważono również, że w przestrzeniach osiedlowych powstaja nowe place zabaw oraz sitownie zewnetrzne, co jest najprawdopodobnie wynikiem otrzymania dotacji unijnych. Jednak ich liczba jest nieodpowiednia, a ich lokalizacja często uniemoż liwia korzystanie z nich przez wszystkich mieszkańców osiedla.

W osiedlach zaobserwowano niedostosowane dla niepełnosprawnych rozwiązania terenowe. Liczne bariery architektoniczne obecne są również w obrębie samych obiektów. W budynkach brakuje wind, pochylni, a klatk schodowe posiadają nieodpowiednie parametry

Atutem kieleckich osiedli jest występowanie w ich obrębie dość dużej ilości przedszkoli, żłobków i szkół, a także dość dobrze rozwinięta strefa usług podstawowych typu handel, przychodnie, czy apteki. Fakt ten znacząco odróż nia osiedla prefabrykowane od współcześnie budowaby the author)
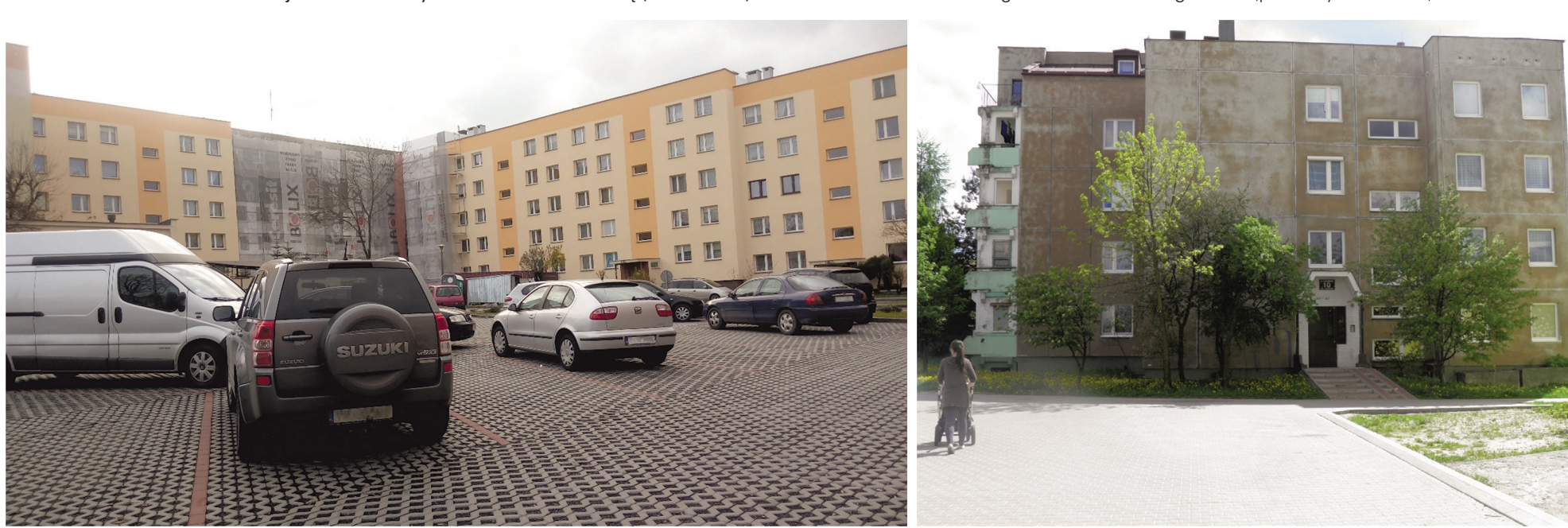

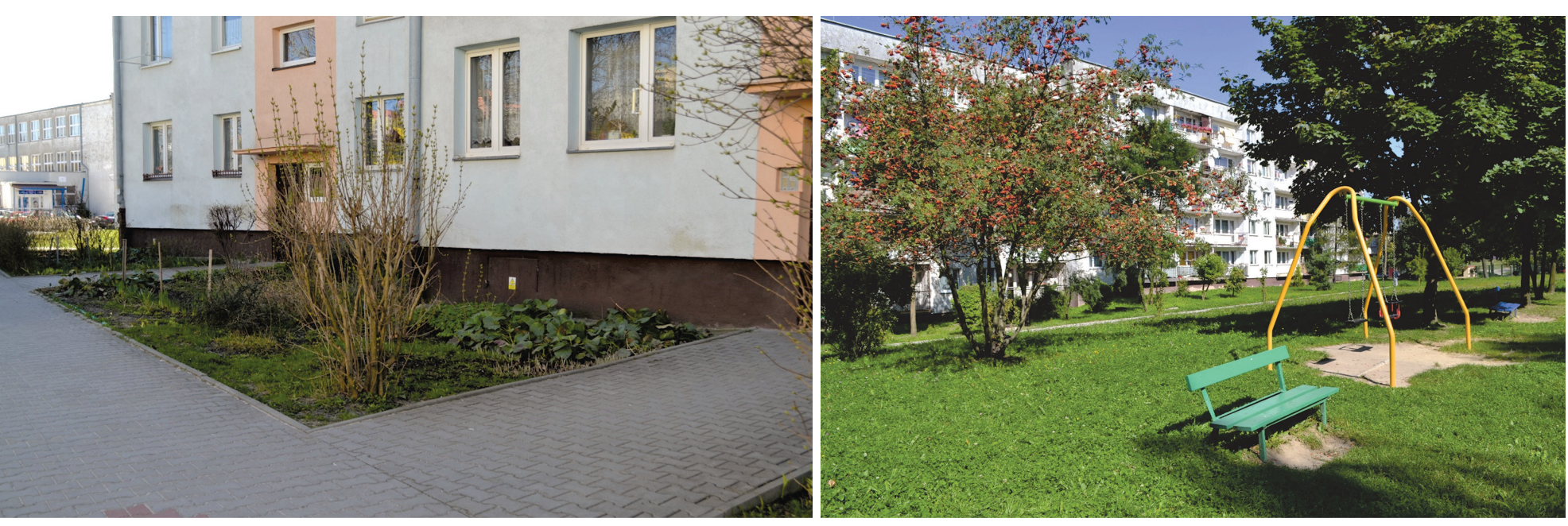

1. 7. Ogródki przydomowe. Osiedle Bocianek (fot. autorka) / Home gardens. Bocianek housing estate. (photo by the author)

II. 8. Plac zabaw. Osiedle Barwinek (fot. autorka) / Playground. Barwinek housing estate. (photo by the author)

nych zespołów, w których w szczególności brakuje szkół i przeszkoli.

$W$ osiedlach $z$ wielkiej płyty zaobserwowano dwa rodzaje lokalizacji usług. Jedna to typ rozproszony np. na osiedlu Ślichowice, gdzie sklepy znajduja sie w parterach budynków oraz w przyulicznych budkach. Drugi rodzaj lokalizacji usług obserwowany jest na osiedlu Barwinek, gdzie usługi skupione są $w$ jednym miejscu w północnej części osiedla.

Na osiedlach zaobserwowano nieliczne obiekty o charakterze kulturalnym. Między innymi na osiedlu Barwine obecne są klub młodzieżowy "Na Barwinku", Osrode Sportowy Orlik i Miejska Biblioteka Publiczna. Obiekty te wymagają rozwinięcia programu funkcjonalnego, a budynki, w których są zlokalizowane wymagają remontu bądź przebudow

Architektura budynków wybudowanych w technologii wielkopłytowej jest dość monotonna. Wnętrza obiektów są mocno zaniedbane i zniszczone. Wymagają ge neralnego remontu. Budynki z wielkiej płyty w Kielcach częściowo zostały poddane termomodernizacji. Wnętrza obiektów nie posiadają powiązania z zewnętrzem. Mieszkania wyposazone są $w$ niewielkie i niefunkcjonalne balkony. Mieszkancy najczęsciej wykorzystuja je do suszeina ubrań. Meszkania w parterch no posiadają táasów niewio no nyine czesto wyposażone sa w ciemna kuchni W zespotach wyróżniono szereg miesicc o ven Wa zesoch ność samochodów w przestrzeniach , czy też obecrekreacij. Zaobserwować można zniszczone elementy placów zabaw, tawki, oświetlenie, czy kosze na śmieci. Stan techniczy przestrzeni pozostawia wiele do życzenia. Elementy małej architektury posiadaja nieciekaw estetyke oraz sa zniszczone.

$W$ przestrzeni kieleckich zespołów wielkopłytowych brakuje założeń wodnych, które jak wynika z literatury maja niezwykle pozytywny wpływ na odbiór estetyczny i mikroklimat otoczenia. side booths. The second type of service location is observed at the Barwinek housing estate, where services are concentrated in one place in the northern part of the estate.

ew cultural facilities were observed in the housin estates. Among others, the "Na Barwinku" youth club, the Orlik Sports Centre and the Municipal Pubic Library are at the Barwinek housing estate. Thes facilities require the development of a functional program, and the buildings in which they are located require renovation or reconstruction.

The architecture of buildings built in large-pane The cilites is a very negect quire major renovation. The large-panel buildings in provement. The interiors of facilities have no connection with the outside. The apartments are equipped with small and non-functional balconies. Residents most often use them for drying clothes. Ground floo apartments do not have terraces or gardens. Smal windows are not conducive to external relations. Buildings, in particular 11-floor buildings, often have a dark kitchen.

The complexes distinguished a number of places with negative aesthetic values, including: garbage bins, or the presence of cars in spaces intended for recreation. There were damaged elements of playgrounds, benches, lighting, or litter bins. The technial condition of the space leaves much to be desired. Elements of street furniture have uninteresting aesthetics and are damaged.

The space of the Kielce large-panel complexes lacks water elements, which, according to literature, have an extremely positive impact on the aesthetics and the microclimate of the environment. Kielce have undergone some thermal efficiency im
Podsumowanie

Rozwój budownictwa mieszkaniowego II połowy XX wieku w Polsce był wynikiem polityki panstwowej mającej na celu zaspokojenie potrzeb mieszkaniowych powstałych po Il wojnie światowej.

Rozwój cywilizacyjny i ekonomiczny ostatnich lat spowodował zmianę oczekiwań społeczeństwa względem miejsca zamieszkania, jak równiez wzrost wymagań wobec licznych, zużytych technicznie oraz niefunkcjonalnych osiedli prefabrykowanych.

Wśród wielu sfer problemowych dotyczących badanych osiedli można wyróżnić zagadnienia natury architektonicznej, urbanistycznej oraz spolecznej, do ktorych zaliczyć mozemy braki funkcjonalno-uzytkowe, między innymi związane $z$ infrastrukturą komunikacyjną, ja brak zagospodarowania przestrzeni zielonych oraz $\mathrm{n}$ ski standard mieszkan oraz ich słaba estetyka. Jednym ze szczególnie uciązliwych dla mieszkańców jest problem z rozwiązaniem komunikacji kołowej, który stanow przyczynę dużego dyskomfortu nawet $w$ dość dobrze ozwiazzanych osiedlach.

Zagadnienia poruszone w artykule dotyczą współczesnych problemów architektoniczno-przestrzennych obserwowanych w osiedlach wielkopłytowych, jak i wskazuja na ich zalety. Zdaniem autorki kieleckie osiedla mieszkaniowe wybudowane w technologi z wielkiej plyty posiadają liczne atuty, ktore niewątpliwie wplywaja na ich clągle zainteresowanie wśród dzy innymi jak i wýć dużych niezagosa do nich mié derenów zielonych, w ustugi, takie jak przedszolo czy szkoty baźz powierzchni samych lokali, które swoim metrażem powowiadia obenym standardom. Zdaniem autorki lety te wpływaia na dominacje pogladów mówiacych - wiekszych korzyściach płynacych z przeksztatcen osiedli z wielkiei ptyty. W zwizzk z powyżzym odpowiednie podéście oraz wykorystanie zauważonch zalet mogtoby stać sie ich atutem, wyróziniacym spośród wspótczesnych zespotów oraz wptywajacym na ich większe zainteresowanie wśród kupujacych. Odpowiednio przeprowadzone prace rehabilitacyine tych osiedli mogłyby wpłynać na ich aktywizacje co z kole miałoby wptyw na ozywienie martwych" w tym momencie części Kielc.

PRZYPISY

1'Tego typu ziawisko prezentuja przyklady osiedli Hellersdorf lub Marzahn
w Berlinie opisane w artykutach: Szczerek E. Rewitalizacja wielkophyto-

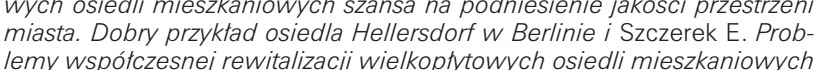
lemy wssoótczesnej rewitalizacji wielkophtytowych osiedli mieszkaniowych na przyktadzie berlíŕskiego osiedla Marzahn
2 Rezerwat Skalny im. Jana Czarnockizo. . Rezerwat przyrody nieożywio kim. Rezerwat utworzono w celu zachowania odkrywki skalnej, przedsta

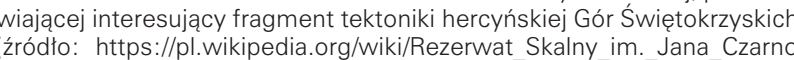
ckiego) Informacje o rozwoju osiedliz wielkie plyty w Kielcach opisane zostaty
w pracy Mochocka S., Rehabilitacia przestrzeni kieleckich osiedli mieszkaniowych z lat 1960-1990 pod katem wspóttzessnych potrzeb. Rozroraw doktorska pod kierrunkiem prof. dr hab. inż. arch. Wactawa Serugi, Kraków
2019. Opracowanie na podstawie dokumentów udostępnionych przzz zarządców kieleckich Spótdzielni Mieszkaniowych.
Summary

The development of residential housing in the second half of the 20th century in Poland was the result of state policy aimed at satisfying housing needs arising after World War II.

The civilization and economic development of recent years has changed the society's expectations regarding the place of residence, as well as the increased requirements for numerous technically worn and non-functional prefabs.

Among many issues related to the examined housAm cial probs, such as uility deficion and so-

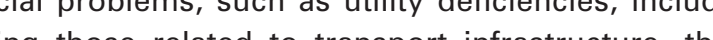
ing lack of green area dovelopment, as well as the low standar of apantmonts and heir poor aesthetics. problem with road transpont, which is the case problem with road transport, which is the cause of great discomfort even in fairly well-develope housing estates.

The issues raised in the article relate to contemporary architectural and spatial problems observed in large-panel housing estates, but also indicate their advantages. According to the author, the largepanel housing estales of Kielce have many assets, which undoubtedly affect their continuous interest among buyers and lessors. These include, among others, the presence of large undeveloped green areas, landscape features, and services, such as nursery schools or schools, or the surfaces of the premises, which by their size correspond to current standards. According to the author, these conveniences prevail in the opinions about the greater benefits from transformations of large-panel housing estates. Therefore, the right approach and the use of perceived pluses could become their advantage, distinguishing them from modern complanand becoming more attractive among buyers. Properly conduct renovation works of these houswould have an inpact on the revival of the "durn would have an

ENDNOTES

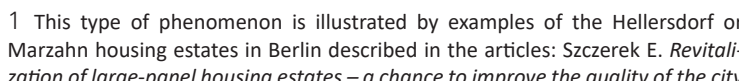

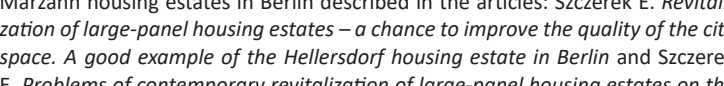

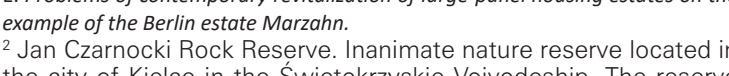
the city of Kielce in the SWiettokrzyskie Voivodeship. The reserve
was created to preserve a rocky zarea with an interesting fragme of the Hercynian tectonics of the Ś Swietokrzyskie Mountains. (sour-
ce: https://pl.wikipedia.org/wiki/Rezerwat_Skalny_im._Jana_Czar3 Information about the develooment of large-panel housing es
tates in Kielce is described in the work of Mochocka S., Restore tates in Kielce is described in the work of Mochocka s. Restora
tion of Kielce housisg estates from $1960-1990$ in terms of modern
needs Doctoral dissertation under the supervision of prof. dr hat needs, Doctoral dissertation under the supervision of prof. dr hab
inzi. arch. Wactaw Seruga, Krakow 2019 Prepared on the basis of
documents made available by the managers of Kielce Housing Cooperatives 


\section{LITERATURA}

[1] Mochocka S., Rehabilitacja przestrzeni kieleckich osiedli mieszkaniowych z lat 1960-1990 pod katem współczesnych potrzeb, Rozprawa doktorska pod kierunkiem prof. dr hab. inż. arch. Wacława Serugi, Kraków 2019

[2] Diagnoza funkcjonalno-przestrzenna osiedli: Olszy i Ugorka praca powstała w Katedrze Kształtowania Środowiska Mieszkaniowego Wydziału Architektury Politechniki Krakowskiej, kierownik projektu: Dr hab. inż. arch. Justyna Kobylarczyk, prof. PK, ekspert: Prof. dr hab. inż. arch. Grażyna Schneider-Skalska, członkowie zespołu: Dr inż. arch. Patrycja Haupt, Dr inż. arch. Kinga Racoń-Leja, Mgr inż. arch. Wojciech Sumlet, Mgr inż. arch. Paweł Tor

[3] Gronostajska B. E. Kreacja i modernizacja przestrzeni mieszkalnej: teoria i praktyka na przykładzie wybranych realizacji wrocławskich z lat 1970-1990, Oficyna Wydawnicza Politechniki Wrocławskiej, Wrocław 2007

[4] Komar B., Wspótczesna jakość spółdzielczej przestrzeni osiedlowej w świetle zasad rozwoju zrównoważonego na wybranych przykładach, wydawnictwo Politechniki Śląskiej, Gliwice 2014

[5] Szczerek E., Rewitalizacja wielkopłytowych osiedli mieszkaniowych szansa na podniesienie jakości przestrzeni miasta. Dobry przykład osiedla Hellersdorf w Berlinie, Czasopismo Techniczne Architektura, Wydawnictwo PK, Kraków 2012

[6] Szczerek E., Problemy współczesnej rewitalizacji wielkopłytowych osiedli mieszkaniowych na przykładzie berlińskiego osiedla Marzahn, Czasopismo Techniczne Architektura, Wydawnictwo PK, Kraków 2012

\section{ŹRÓDŁA INTERNETOWE:}

https://pl.wikipedia.org/wiki/Rezerwat_Skalny_im._Jana_Czarnockiego (dostęp: 19.08.2019)

http://www.gis.kielce.eu/ (dostęp:19.08.2019)

\section{BIBLIOGRAPHY}

[1] Mochocka S., Rehabilitacja przestrzeni kieleckich osiedli mieszkaniowych z lat 1960-1990 pod kątem wspótczesnych potrzeb. PhD thesis under the supervision of prof. dr hab. inż. arch. Wacław Seruga, Krakow 2019

[2] Functional and spatial diagnosis of the Olszy i Ugorka housing estates. The work was created in the Department of Housing Development at the Faculty of Architecture of the Cracow University of Technology, project manager: Dr hab. inż. arch. Justyna Kobylarczyk, prof. PK, expert: Prof. dr hab. inż. arch. Grażyna Schneider-Skalska, team members: Dr inż. arch. Patrycja Haupt, Dr inż. arch. Kinga Racoń-Leja, Mgr inż. arch. Wojciech Sumlet, Mgr inż. arch. Paweł Tor [3] Gronostajska B. E. Kreacja i modernizacja przestrzeni mieszkalnej: teoria i praktyka na przykładzie wybranych realizacji wrocławskich z lat 1970-1990, Oficyna Wydawnicza Politechniki Wrocławskiej, Wrocław 2007

[4] Komar B., Wspótczesna jakość spółdzielczej przestrzeni osiedlowej w świetle zasad rozwoju zrównoważonego na wybranych przykładach, wydawnictwo Politechniki Śląskiej, Gliwice 2014

[5] Szczerek E., Rewitalizacja wielkoptytowych osiedli mieszkaniowych szansa na podniesienie jakości przestrzeni miasta. Dobry przykład osiedla Hellersdorf w Berlinie, Czasopismo Techniczne Architektura, Wydawnictwo PK, Kraków 2012

[6] Szczerek E., Problemy wspótczesnej rewitalizacji wielkoptytowych osiedli mieszkaniowych na przykładzie berlińskiego osiedla Marzahn, Czasopismo Techniczne Architektura, Wydawnictwo PK, Kraków 2012

\section{INTERNET SOURCES:}

https://pl.wikipedia.org/wiki/Rezerwat_Skalny_im._Jana_Czarnockiego (access: 19.08.2019)

http://www.gis.kielce.eu/ (access:19.08.2019 